\title{
PENGARUH EFEKTIVITAS KERJA TERHADAP KINERJA PEGAWAI PADA KANTOR BADAN PENYELENGGARA JAMINAN SOSIAL KOTA BANDAR LAMPUNG
}

\author{
Husna Purnama ${ }^{(1)}$, Syaipuddin ${ }^{(2)}$ \\ Fakultas Ekonomi Universitas Sang Bumi Ruwa Jurai \\ husna.purnama@fe.saburai.ac.id, syaipuddin69@gmail.com
}

\begin{abstract}
Abstrak. Upaya peningkatan kinerja pegawai dapat ditempuh dengan berbagai cara, salah satunya adalah dengan efektifitas pegawai serta peningkatan kualitas pelayanan. Masalah yang dihadapi pada penelitian ini adalah efektifitas kerja kurang maksimal. Tujuan Penelitian ini adalah Untuk mengetahui berapa besar pengaruh efektivitas kerja terhadap kinerja pegawai pada Kantor Badan Penyelanggara Jaminan Sosial Kota Bandar Lampung. Penelitian yang akan dilaksanakan jenis Penelitian deskriptif, jenis penelitian ini adalah penelitian yang bermaksud membuat pemaparan secara sistimatis, faktual, dan akurat mengenai fakta - fakta dan sifat - sifat populasi tertentu. Penelitian ini menggunakan 31 responden penelitian. Ada dua variabel dalam penelitian ini yaitu: Variabel bebas $(\mathrm{X})$ dan variable terikat $(\mathrm{Y})$. Dari hasil pengolahan data telah berhasil ditemukan jawaban hipotesis yaitu terdapat pengaruh efektifitas $(\mathrm{X})$ terhadap kinerja $(\mathrm{Y})$ sebesar $95,9 \%$.
\end{abstract}

Kata kunci: Efektivitas, Kinerja, Pegawai, Peningkatan.

\section{PENDAHULUAN}

Penyelenggaraan program jaminan sosial merupakan salah satu tanggung jawab dan kewajiban negara untuk memberikan perlindungan sosial ekonomi kepada masyarakat. Sesuai dengan kondisi kemampuan keuangan negara. Indonesia seperti halnya negara berkembang lainnya, mengembangkan program jaminan sosial berdasarkan funded social security, yaitu jaminan sosial yang didanai oleh peserta dan masih terbatas pada masyarakat pekerja di sektor formal.

Adanya pengeluaran yang tidak terduga apabila seseorang terkena penyakit, apalagi tergolong penyakit berat yang menuntut stabilisasi yang rutin seperti hemodialisa atau biaya operasi yang sangat tinggi. Hal ini berpengaruh pada penggunaan pendapatan seseorang dari pemenuhan kebutuhan hidup pada umumnya menjadi biaya perawatan dirumah sakit, obatobatan, operasi, dan lain lain. Hal ini tentu menyebabkan kesukaran ekonomi bagi diri sendiri maupun keluarga. Sehingga munculah istilah "SADIKIN", sakit sedikit jadi miskin.Dapat disimpulkan, bahwa kesehatan tidak bisa digantikan dengan uang, dan tidak ada orang kaya dalam menghadapi penyakit karena dalam sekejap kekayaan yang dimiliki seseorang dapat hilang untuk mengobati penyakit yang dideritanya.

Begitu pula dengan resiko kecelakaan dan kematian. Suatu peristiwa yang tidak kita harapkan namun mungkin saja terjadi kapan saja dimana kecelakaan dapat menyebabkan merosotnya kesehatan, kecacatan, ataupun kematian karenanya kita kehilangan pendapatan, baik sementara maupun permanen. Belum lagi menyiapkan diri pada saat jumlah penduduk lanjut usia dimasa datang semakin bertambah.

Pada tahun 2030, diperkirakan jumlah penduduk Indonesia adalah 270 juta orang.70 juta diantaranya diduga berumur lebih dari 60 tahun. Dapat disimpulkan bahwa pada tahun 2030 terdapat $25 \%$ penduduk Indonesia adalah lansia. 
Lansia ini sendiri rentan mengalami berbagai penyakit degeneratif yang akhirnya dapat menurunkan produktivitas dan berbagai dampak lainnya. Apabila tidak ada yang menjamin hal ini maka suatu saat hal ini mungkin dapat menjadi masalah yang besar.

Pada saat mulai berlakunya UU BPJS, Dewan Komisaris dan Direksi PT Askes (Persero) dan PT Jamsostek (Persero) ditugasi oleh UU BPJS untuk menyiapkan berbagai hal yang diperlukan untuk berjalannya proses tranformasi atau perubahan dari Persero menjadi BPJS dengan status badan hukum publik. Perubahan tersebut mencakup struktur, mekanisme kerja dan juga kultur kelembagaan.

Faktor utama yang membedakan untuk perusahaan-perusahaan jasa adalah kualitas layanan pelanggan. Menurut Payne (2009), para pelanggan semakin pandai berkaitan dengan permintaan mereka dan menuntut standar layanan yang semakin meningkat. Saat ini perusahaan jasa menyadari untuk memperbaiki layanan pelanggan untuk menghadapi persaingan dalam lingkungan jasa yang sangat kompetitif. Untuk mengukur kualitas layanan diperlukan pendekatan melalui model penentu kualitas jasa dan dukungan dari model penentu mutu.

Semakin baik kinerja karyawan, maka semakin besar kemungkinan pelanggan untuk puas. Menurut Aaker (2006), kepuasan adalah ukuran sebenarnya tentang bagaimana penerimaan dan kesesuaian konsumen terhadap suatu merek, dan kepuasan adalah ukuran sebenarnya untuk bisnis jasa, selain kesetiaan pelanggan yang berdasarkan pengalaman menyenangkan.

Fenomena yang terjadi pada efektifitas pegawai belum maksimal karena banyak pegawai yang menunda-nunda pekerjaan dan mengerjakan yang bukan tugasnya di saat jam kerja. Dalam upaya mencapai tujuan organisasinya terkendala oleh masalah Pelatihan pegawai, masih banyak pegawai yang perlu mengikuti Pelatihan. Di samping itu kendala lain adalah atau Pelatihan tidak sesuai dengan tupoksi di dinas. Pelatihan yang diberikan oleh dinas belum sepenuhnya sesuai yang diharapkan untuk menunjang pekerjaan.

Fenomena yang terjadi pada Di Kantor Badan Penyelenggara Jaminan Sosial (BPJS) Ketenagakerjaan Lampung adalah Masih adanya beberapa pegawai yang kualitas pelayanannya menurun sedangkan pemberian pendidikan tetap didapatkan. Masih adanya pegawai yang mempunyai pelatihan kerja yang rendah, hal ini terlihat dari kurangnya semangat dan gairah kerja.

Masih dirasakan kurangnya Pelatihan kerja yang diberikan pimpinan baik Pelatihan kerja material maupun Pelatihan kerja non material. Pelatihan kerja belum maksimal, hal ini ditunjukkan dengan masih banyak pekerjaan yang tidak selesai tepat pada waktunya karena pelatihan kerja yang diberikan tidak diaplikasikan pada pelaksanaan pekerjaan.

Kualitas pelayanan belum optimal, pelayanan masih terasa lambat dan terbentur dengan birokrasi yang panjang dan berbelit-belit. Berdasarkan hal tersebut, maka peneliti tertarik untuk meneliti lebih lanjut mengenai fenomena tersebut dengan judul: "Pengaruh Efektivitas Kerja terhadap Kinerja Pegawai pada Kantor Badan Penyelenggara Jaminan Sosial Kota Bandar Lampung".

\section{KAJIAN TEORI}

\section{Pengertian Efektivitas kerja}

Pada umumnya efektivitas sering dihubungkan dengan efisiensi dalam pencapaian tujuan organisasi. Padahal suatu tujuan atau saran yang telah tercapai sesuai engan rencana dapat dikatakan efektif, tetapi belum tentu efisien. Walaupun terjadi suatu peningkatan efektivitas dalam suatu 
organisasi maka belum tentu itu efisien. jelasnya, jika sasaran atau tujuan telah tercapai sesuai dengan yang direncanakan sebelumnya dapat dikatakan efektif. Jadi bila suatu pekerjaan itu tidak selesai sesuai waktu yang telah di mencapai sasaran yang telah ditetapkan dan adanya keterkaitan antara nilai - nilai yang bervariasi.

Efektivitas memiliki arti berhasil atau tepat guna. Efektif merupakan kata dasar, sementara kata sifat dari efektif adalah efektivitas. Komunikasi yang prosesnya mencapai tujuan yang direncanakan sesuai dengan biaya yang dianggarkan, waktu yang ditetapkan dan jumlah personil yang ditentukan (Effendy, 2005). Pengertian efektivitas menurut Hadayaningrat (2007) adalah "Efektivitas adalah pengukuran dalam arti tercapainya sasaran atau tujuan yang telah ditentukan sebelumnya".

Pendapat Hadayaningrat mengartikan efektivitas bisa diartikan sebagai suatu pengukuran akan tercapainya tujuan yang telah direncanakan sebelumnya secara matang. Berdasarkan pendapat kedua di atas efektivitas adalah suatu komunikasi yang melalui proses tertentu, secara terukur yaitu tercapainya sasaran atau tujuan yang ditentukan sebelumnya. Dengan biaya yang dianggarkan, waktu yang ditetapkan dan jumlah orang yang telah itentukan.Apabila ketentuan tersebut berjalan dengan lancar, maka tujuan yang direncanakan akan tercapai sesuai dengan yang diinginkan.

\section{Faktor-Faktor yang Mempengaruhi Efektivitas Kerja}

Ada empat faktor yang mempengaruhi efektivitas kerja, seperti yang dikemukakan oleh Richard M. Steers (2008), yaitu:

1. Karakteristik organisasi, terdiri dari struktur dan teknologi organisasi yang dapat mempengaruhi segi-segi tertentu dari efektivitas dengan berbagai cara.

2. Karakteristik Lingkungan, Lingkungan luar dan lingkungan dalam juga telah dinyatakan berpengaruh atas efektivitas, keberhasilan hubungan organisasi lingkungan tampaknya amat tergantung pada tingkat variabel kunci yaitu tingkat keterdugaan keadaan lingkungan, ketepatan persepsi atas keadaan lingkungan, tingkat rasionalisme organisasi.

3. Karakteristik Pekerja, Pada kenyataannya para anggota organisasi merupakan faktor pengaruh yang paling penting. Pekerja merupakan sumber daya yang langsung berhubungan dengan pengelolaan semua sumber daya yang ada di dalam organisasi, oleh sebab itu perilaku pekerja sangat berpengaruh terhadap pencapaian tujuan organisasi.

4. Karakteristik Kebijaksanaan dan Praktek Manajemen, dengan makin rumitnya proses teknologi dan perkembangannya lingkungan maka peranan manajemen dalam mengkoordinasi orang dan proses demi keberhasilan organisasi semakin sulit.

\section{Pengertian Kinerja}

Menurut Kartini Kartono (2008) kinerja merupakan aktivitas dasar dan bagian esensial dari kehidupan manusia. Sama dengan kegiatan bermain bagi anakanak, maka kerja memberikan kesenangan dan arti tersendiri bagi kehidupan. Sebab kerja itu memberikan status kepada seseorang, dan mengikatkan diri sendiri dengan induvidu-induvidu lain dalam masyarakat.

Kinerja itu tidak hanya berwujud kebutuhan ekonomis yang bersifat materill saja (misalnya berbentuk uang), akan tetapi 
bisa juga berwujud respek / penghargaan dari lingkungan, prestise dan status sosial, yang semuanya merupakan bentuk ganjaran sosial yang imateril sifatnya.

Menurut Mondy (2008) Manajemen Kinerja adalah proses berorientasi tujuan yang diarahkan untuk memastikan bahwa proses-proses keorganisasian ada padatempatnya untuk memaksimalkan produktifitas para karyawan, tim dan akhirnya organisasi. Menurut Irham (2011) Kinerja adalah hasil yang diperoleh oleh suatu organisasi baik organisasi tersebut bersifat profit oriented dan nonprofit oriented yang dihasilkan selama satu periode waktu. Menurut Mangkunegara (2007) Kinerja adalah hasil kerja yang secara kualitas dan kuantitas yang dicapai oleh seseorang pegawai dalam melaksanakan tugasnya sesuai dengan tanggung jawab yang diberikan kepadanya.

\section{Faktor-faktor yang Mempengaruhi Kinerja}

Kemampuan dalam menyelesaikan suatu pekerjaan dengan motivasi kerja yang tinggi dengan melihat peluang-peluang, kekuatan intern organisasi serta sumber daya yang tercukupi akan menciptakan prestasi kerja yang diinginkan bagi karyawan, atasan dan organisasi secara umum. Kinerja sebagai fungsi interaksi antara kemampuan atau ability, motivasi atau motivation dan kesempatan atau opportunity. Artinya kinerja merupakan fungsi dari kemampuan, motivasi dan kesempatan (Robbins, 2007).

Menurut Mangkunegara (2007), faktorfaktor yang mempengaruhi kinerja dipengaruhi oleh 3 faktor, yaitu:

1. Faktor Kemampuan (job ability)

Kemampuan anggota tidak sama ada yang punya kemampuan tinggi atau sebaliknya berkemampuan rendah. Kemampuan diperoleh dari bakat dan pendidikan yang pernah diterimanya.
2. Faktor Keterampilan (skill)

Keterampilan diperoleh dari pendidikan atau pelatihan kerja serta pengalaman kerja.

\section{Faktor Motivasi Kerja (job motivation)} Motivasi kerja lebih dipengaruhi oleh keinginan dan tujuan hidup serta lingkungan kerja sehari-hari yang selalu mempengaruhinya baik itu bersifat positif maupun negatif.

\section{METODE PENELITIAN}

\section{Objek Penelitian}

Dalam penelitian ini yang menjadi Objeknya adalah Kantor Badan Penyelenggara Jaminan Sosial Kota Bandar Lampung. Kantor ini terletak di Jl. Zainal Abidin Pagar Alam No.35 Rajabasa Bandar Lampung. Pelaksanaan penelitian pada bulan April 2016.

\section{Metode dan Teknik Pengumpulan Data}

Metode penelitian yang digunakan adalah metode analisis kualitatif dan kuantitatif yaitu dengan mengadakan riset lapangan dalam rangka mendapatkan datadata dari Kantor Badan Penyelenggara Jaminan Sosial Kota Bandar Lampung. Dalam penelitian ini jenis data yang diperlakukan adalah :

\section{Data Primer}

Data primer merupakan data dasar yang akan diperoleh langsung tanpa perantara orang atau lembaga lain sebagai pihak ketiga. Data primer ini diperoleh dengan wawancara melalui responden dengan menggunakan daftar pertanyaan.

2. Data Sekunder

Data skunder merupakan data yang diperoleh melalui orang lain yang berhubungan dengan permasalahan yang dipecahkan. Data sekunder ini diperoleh 
melalui cara studi dokumenter yaitu mengumpulkan dan mempelajari brosurbrosur serta dokumen organisasi.

\section{Sampel dan Populasi}

Suharsimi Arikunto (2008) mengartikan sampel adalah subyek sesungguhnya dari suatu penelitian. Untuk menetapkan jumlah populasi dijadikan sampel Arikunto (2008) memberikan batasan bahwa untuk jumlah populasi diatas 100 dapat diambil besarnya sample $10 \%$ $15 \%$ atau $20 \%-25 \%$. Dari pengertian diatas maka jumlah populasi adalah seluruh pegawai di Kantor Badan Penyelenggara Jaminan Sosial Kota Bandar Lampung berjumlah 31 responden.

\section{Metode Analisis Data}

Untuk pengolahan data dalam bentuk tabulasi hasil jawaban responden kemudian dilakukan analisis data melalui metode analisis secara kualitatif dan analisis kuantitatif.

Analisis kualitatif merupakan analisis yang dinyatakan dalam bentuk uraian dan didasarkan pada data yang telah ada. Data kualitatif merupakan data berupa informasi yang kemudian dikaitkan dengan data lainnya sehingga memunculkan suatu kebenaran.

Analisis kuantitatif yang dilakukan berdasarkan data primer yang diperoleh dari penyebaran instrument (daftar pertanyaan) kepada sampel, dan untuk mengetahui pengaruh dari variabel bebas (independent variable) terhadap variabel terikat (dependent variable).

Persamaan Regresi Linear Sederhana menentukan persamaan regresi linear sederhana untuk $\mathrm{X}$ :

$$
Y=a+b X+e
$$

Keterangan:

$$
\begin{aligned}
& \mathrm{Y}=\text { Kinerja Pegawai } \\
& \mathrm{a}=\text { Konstanta } \\
& \mathrm{b}=\text { Koefisien regresi } \mathrm{X} \\
& \mathrm{X}=\text { Efektivitas Kerja } \\
& \mathrm{e}=\text { Faktor kesalahan }
\end{aligned}
$$

Untuk mengetahui besarnya pengaruh, penghitungan koefisien korelasi tersebut kemudian dilanjutkan dengan Rumus Koefisien Determinasi atau Koefisien Penentu (KP):

$$
K P=(r)^{2} x 100 \%
$$

Untuk menguji secara hipotesis secara parsial digunakan Uji t dengan rumus :

$$
t_{\text {hitung }}=\frac{r \sqrt{N-2}}{\sqrt{1-r^{2}}}
$$

Keterangan:

$$
\begin{array}{ll}
\mathrm{t}_{\text {hitung }} & =\text { Nilai } \mathrm{t} \\
\mathrm{r} & =\text { Koefisien Korelasi } \\
\mathrm{N} & =\text { Jumlah responden }
\end{array}
$$

Kriteria untuk Uji $\mathrm{t}$ adalah sebagai berikut :

a) Jika $t_{\text {hitung }}>t_{\text {tabel }}$ maka Ha diterima dan Ho ditolak.

b) Jika $t_{\text {hitung }} \leq \mathrm{t}_{\text {tabel }}$ maka Ha ditolak dan Ho diterima.

Taraf signifikan dalam penelitian ini digunakan $\alpha=0,05$ atau 5\%. Yang dimaksud dengan Hipotesis nol (Ho) dan Hipotesis alternatif $(\mathrm{Ha})$ adalah :

Ho $=r \leq 0=$ Berarti tidak ada pengaruh efektivitas kerja terhadap kinerja pegawai $\mathrm{Ha}=\mathrm{r}>0=$ Berarti ada pengaruh efektivitas kerja terhadap kinerja pegawai.

\section{HASIL DAN PEMBAHASAN}

Berdasarkan hasil perhitungan tingkat korelasi antar variable diperoleh besarnya 
tingkat korelasi antara variabel efektifitas kerja (X) dengan variabel kinerja pegawai (Y) pada Badan Penyelenggara Jaminan Sosial (BPJS) Bandar Lampung adalah sebesar 0,972. Jika dikonsultasikan dengan tabel Interpretasi koefesien korelasi (Sugiyono) maka tingkat korelasi efektifitas kerja $(\mathrm{X})$ dengan variabel kinerja pegawai (Y) pada Badan Penyelenggara Jaminan Sosial (BPJS) Bandar Lampung dalam kategori korelasi "sangat kuat" yakni terletak pada $0,800-0,100$.

Uji validitas digunakan untuk menguji sejauh mana ketepatan alat pengukur dapat mengungkapkan konsep gejala/kejadian yang diukur. Pengujian validitas dilakukan dengan menggunakan rumus korelasi. Pengujian validitas selengkapnya dapat dilihat pada Tabel 1.

Hasil perhitungan koefisien determinasi menunjukkan $(\mathrm{KD})=\mathrm{R}^{2}=$ $0,959=95,9 \%$. dapat disimpulkan bahwa variabel efektifitas kerja (X) menjelaskan variasi perubahan terhadap variabel kinerja pegawai (Y) Badan Penyelenggara Jaminan Sosial (BPJS) Bandar Lampung sebesar 95,9\%, sedangkan sisanya dijelaskan oleh faktor lain yang tidak dikaji dalam penelitian ini.

Berdasarkan hasil Uji t didapat bahwa nilai $t_{\text {hitung }}=35,938$. Apabila dibandingkan dengan $t_{\text {tabel }}$ pada taraf signifikan yaitu 1,6720 , maka $t_{\text {hitung }}=35,938>\mathrm{t}_{\text {tabel }}=1,6720$ sehingga dapat disimpulkan bahwa; Ha yang menyatakan terdapat pengaruh antara variabel efektifitas kerja (X) terhadap variabel kinerja pegawai (Y) Badan Penyelenggara Jaminan Sosial (BPJS) Bandar Lampung dapat diterima. Jadi variabel efektifitas kerja (X) berpengaruh terhadap variabel kinerja pegawai (Y).

Persamaan regresi antara variabel efektifitas kerja (X) terhadap variabel kinerja pegawai (Y) Badan Penyelenggara Jaminan Sosial (BPJS) Bndar Lampung adalah $\mathrm{Y}=1,821+0,918 \mathrm{X}$, yang artinya setiap kenaikan satu poin dari variabel efektifitas kerja akan diikuti oleh naiknya variabel kinerja pegawai Badan Penyelenggara Jaminan Sosial (BPJS) Bandar Lampung sebesar 0,918 poin.

Dari hasil penelitian dinyatakan bahwa efektifitas kerja pada Badan Penyelenggara Jaminan Sosial (BPJS) Bandar Lampung dalam kategori baik. Hasil perhitungan tingkat korelasi antara variabel efektifitas kerja (X) dengan kinerja pegawai (Y) sebesar 0,979 termasuk dalam kategori sangat kuat yakni $0,800-0,100$.

\section{KESIMPULAN DAN SARAN}

\section{Kesimpulan}

Berdasarkan penelitian dapat disimpulkan bahwa variabel efektifitas kerja (X) menjelaskan variasi perubahan terhadap variabel kinerja pegawai $(\mathrm{Y})$ Badan Penyelenggara Jaminan Sosial (BPJS) Bandar Lampung sebesar 95,9\%, sedangkan sisanya dijelaskan oleh faktor lain yang tidak dikaji dalam penelitian ini. $\mathrm{Y}=1,821+0,918 \mathrm{X}$, yang artinya setiap kenaikan satu poin dari variabel efektifitas kerja akan diikuti oleh naiknya variabel inerja pegawai sebesar 0,918 poin. Uji hipotesis parsial melalui uji $\mathrm{t}$ (test) diperoleh nilai thitung antara efektifitas kerja terhadap kinerja pegawai sebesar thitung $=35,938>\quad t_{\text {tabel }}=1,6720, \quad$ ini menunjukkan bahwa efektivitas kerja berpengaruh terhadap kinerja pegawai pada Badan Penyelenggara Jaminan Sosial (BPJS) Bandar Lampung.

\section{Saran}

Adapun saran yang diajukan peneliti adalah sebagai berikut:

1. Variabel efektifitas kerja yang perlu mendapat perhatian adalah pegawai mengeluh terhadap pekerjaan yang diemban, hal ini dapat ditingkatkan dengan memberikan motivasi kepada 
pegawai agar selalu mengerjakan tupoksi dengan penuh tanggung jawab dan merupakan kewajiban terhadap setiap pegawai untuk menyelesaikan semua pekerjaan.

2. Pada variabel kinerja pegawai yang perlu ditingkatkan adalah kondisi lingkungan kerja yang nyaman. Untuk saat ini kondisi kerja terutama ruangan kurang nyaman, hal ini membuat kinerja pegawai menurun karena merasa tidak betah berlama-lama diruangan. Solusi untuk hal ini adalah merenovasi ruangan agar kondisi menjadi nyaman dan pegawai betah bekerja dalam ruangan.

\section{DAFTAR PUSTAKA}

Aaker. 2006. Evaluasi Kinerja Keuangan Bank-Bank Pemerintah.

Adrian, Payne. 2009. Service Marketing Pemasaran Jasa. Yogyakarta: Penerbit Andi.

Arikunto Suharsimi, 2008. Prosedur Penelitian Suatu Pendekatan Praktek. Jakarta: Rineka Cipta.

Effendy. 2005. Manajemen Sumber Daya Manusia. Bandung: Ramadan.

Fahmi, Irham. 2011. Manajemen Teori, Kasus dan Solusi. Bandung: Alfabeta.

Kartono, Kartini. 2006. Psikologi Umum. Bandung: CV Mandar Maju.

Mangkunegara, Anwar Prabu. (2007). Evaluasi Kinerja SDM. Jakarta: Eresco.

Robbins, Stephens P. 2007. Prinsip-prinsip Perilaku Organisasi, alih bahasa oleh Halida dan Dewi Sartika, Edisi Kelima. Jakarta: Erlangga.
Sedarmayanti. 2010. Metode Penelitian Survei. Jakarta: LP3ES.

Sugiyono. 2008. Metode Penelitian Bisnis. Bandung: Penerbit Alphabeta.

Sulistiyani, Ambar Teguh, dan Rosidah. 2007. Manajemen Sumber Daya Manusia. Graha Ilmu: Yogyakarta.

Suradinata. 2009. Statistika Untuk Penelitian Cetakan Keenam. Bandung: Alfabeta.

Widodo. 2008. Psikologi Belajar. Jakarta: Rineka. 